\title{
Risk assessment of heavy metals in the surface sediment at the drinking water source of the Xiangjiang River in South China
}

Zhifeng Huang ${ }^{1,2}$, Chengyou Liu $^{1}$, Xingru Zhao ${ }^{1 *} \mathbb{C}$, Jing Dong ${ }^{1}$ and Binghui Zheng ${ }^{1 *}$

\begin{abstract}
Background: The Xiangjiang River is an important drinking water resource for the Hunan Province of China. It is crucial to ascertain the pollution status, influencing factors, ecological risks, and possible sources of heavy metals in the sediments of the Xiangjiang River. Sediment is both a source and a sink of heavy metals in aquatic ecosystems. In this study, surface sediment was collected from the Zhuzhou Reach of the Xiangjiang River and eight heavy metals were investigated.

Results: In all sediment samples, all eight heavy metals were detected and their average concentration fell in the order of $\mathrm{Zn}>\mathrm{Pb}>\mathrm{As}>\mathrm{Cu}>\mathrm{Cr}>\mathrm{Ni}>\mathrm{Cd}>\mathrm{Co}$. Assessment shows extremely serious $\mathrm{Cd}$ pollution and a very high potential ecological risk from $\mathrm{Cd}$. According to correlation analysis and principal component analysis (PCA), As, $\mathrm{Cu}, \mathrm{Ni}, \mathrm{Pb}$, and $\mathrm{Zn}$ originate from industrial wastewater and mineral smelting activities, whereas $\mathrm{Co}, \mathrm{Cr}$, and $\mathrm{Ni}$ come from natural sources. Redundancy analysis (RDA) reveals that the organic matter content and the particle size of the sediment have a certain influence on the enrichment of heavy metals.

Conclusion: Among all eight examined heavy metals in the surveyed area, the content of $\mathrm{Zn}, \mathrm{Pb}$, and $\mathrm{As}$ is the highest, and that of $\mathrm{Cd}$ and $\mathrm{Co}$ is the lowest. Despite a low level of absolute content, the $\mathrm{Cd}$ in sediment already renders a high ecological risk and thus calls for urgent attention. Anthropogenic activities are the main source of heavy metals in the sediment. The distribution of heavy metals may also be influenced by sediment properties. The results provide guidance for controlling heavy metal pollution and protecting drinking water sources in the Xiangjiang River.
\end{abstract}

Keywords: Heavy metal, Risk assessment, Sediment, Distribution, The Xiangjiang River

\section{Background}

Heavy metals are a pressing concern in terms of their pollution in aquatic ecosystems because of their persistence, environmental toxicity, bioaccumulation, etc. [1-4]. Aquatic environments (e.g., lakes [5], rivers [6], reservoirs [7], and wetlands [8]) receive heavy metals in untreated or inadequately treated wastewater from domestic, industrial, and agricultural sources. Pollution

\footnotetext{
*Correspondence: zhaoxr@craes.org.cn; zhengbinghui@craes.org.cn

${ }^{1}$ National Engineering Laboratory for Lake Pollution Control

and Ecological Restoration, State Environmental Protection Key Laboratory of Drinking Water Source Protection, Chinese Research

Academy of Environmental Sciences, Beijing 100012, China

Full list of author information is available at the end of the article
}

from heavy metals is inflicting rivers worldwide $[9,10]$, especially in developing countries $[11,12]$.

As an important component in riverine ecosystems, sediment serves as both a sink and a source of heavy metals $[13,14]$. Most heavy metals quickly deposit into the sediment after entering rivers, and are much more concentrated in the sediment than in the water body of riverine systems $[15,16]$. Conversely, when the physicochemical or hydrological conditions change, heavy metals in the sediment may desorb or resuspend to cause secondary pollution in the water body $[17,18]$. The accumulation of heavy metals in the sediment directly affects benthic organisms and also influences many other organisms through the food web [19, 20], 
and endangers the wellbeing of the aquatic ecosystem. Therefore, it is of great importance to assess and understand the distribution and accumulation of heavy metals in sediment.

The Xiangjiang River is a major tributary of the Yangtze River and a key river in South China. It flows through the Hunan Province and supports many densely populated cities, providing services to both industry and agriculture [21, 22]. Unfortunately, the Xiangjiang River has become one of the most seriously heavy metal-polluted rivers in China over the past few decades because of the wastewater discharge from mining and metallurgical industries carrying heavy metals [23]. Although many researchers have studied heavy metal pollution in the Xiangjiang River [24-26], a systematic study is still lacking to associate the sediment with the distribution, characteristics, risk assessment, possible sources, and impact of heavy metals.

The Zhuzhou Reach of the Xiangjiang River is a typical area polluted by heavy metals [27]. In this work, we collected 30 surface sediment samples from the Zhuzhou Reach of the Xiangjiang River in order to (1) characterize the occurrence and distribution of eight heavy metals ( $\mathrm{Cd}, \mathrm{As}, \mathrm{Pb}, \mathrm{Zn}, \mathrm{Cu}, \mathrm{Ni}, \mathrm{Cr}$, and $\mathrm{Co}$ ) in the sediment; (2) assess the pollution status and the ecological risk of the heavy metals; (3) identify possible sources of heavy metal pollution from principal component analysis (PCA) and Pearson's correlation analysis, and (4) use redundancy analysis (RDA) to analyze the sediment characteristics that influence heavy metal distribution. The results illuminate on the environmental behavior of heavy metals and provide a reference for controlling pollution and ecological remediation in nearby areas and similar riverine systems.

\section{Materials and methods}

\section{Study area and sample collection}

The Xiangjiang River is the second largest tributary of the Yangtze River and an important drinking water source in South China. The main channel of the river is $856 \mathrm{~km}$ long, and its basin covers $94,721 \mathrm{~km}^{2}$ and supports $>30$ million residents of the Hunan Province [28]. It flows from south to north en route 6 major cities in Hunan, i.e., Yongzhou, Hengyang, Zhuzhou, Xiangtan, Changsha, and Yueyang, and finally joins the Yangtze River via the Dongting Lake. The Hunan Province is known as the "Nonferrous Metal Village" because of its abundant mineral resources (e.g., $\mathrm{Cd}, \mathrm{Zn}, \mathrm{Pb}, \mathrm{Cu}$, etc. [29]). However, the mining and smelting of nonferrous metals over the past years caused severe heavy metal pollution to the Xiangiiang River. The city of Zhuzhou at the east of the Hunan Province is at the lower reaches of the Xiangjiang River. The area is rich in mineral resources and active in mining, ore smelting, and other major industrial practices. Therefore, we chose the Zhuzhou Reach of the Xiangjiang River for pollution evaluation and risk assessment. At the upstream of the surveyed area, there are many companies producing $\mathrm{Zn}, \mathrm{Pb}, \mathrm{As}$, and alloys as well as other companies that carry out comprehensive recovery of $\mathrm{Cu}, \mathrm{Au}, \mathrm{Ag}, \mathrm{Bi}, \mathrm{Te}, \mathrm{Cd}, \mathrm{In}$, and other rare metals. In this work, eight target heavy metals ( $\mathrm{Cd}, \mathrm{As}, \mathrm{Pb}, \mathrm{Zn}, \mathrm{Cu}, \mathrm{Ni}, \mathrm{Cr}$, and $\mathrm{Co}$ ) were chosen for evaluation after examining the actual situation of the study area and consulting literatures on heavy metals in the Xiangjiang River [21, 25, 28].

Ten sampling transects (S1-S10) were selected from upstream to downstream in the investigated area (Fig. 1). Surface sediment samples $(1 \mathrm{~kg})$ were collected in August, 2011 with a core sampler at the north side, in the middle, and at the south side of the river from the
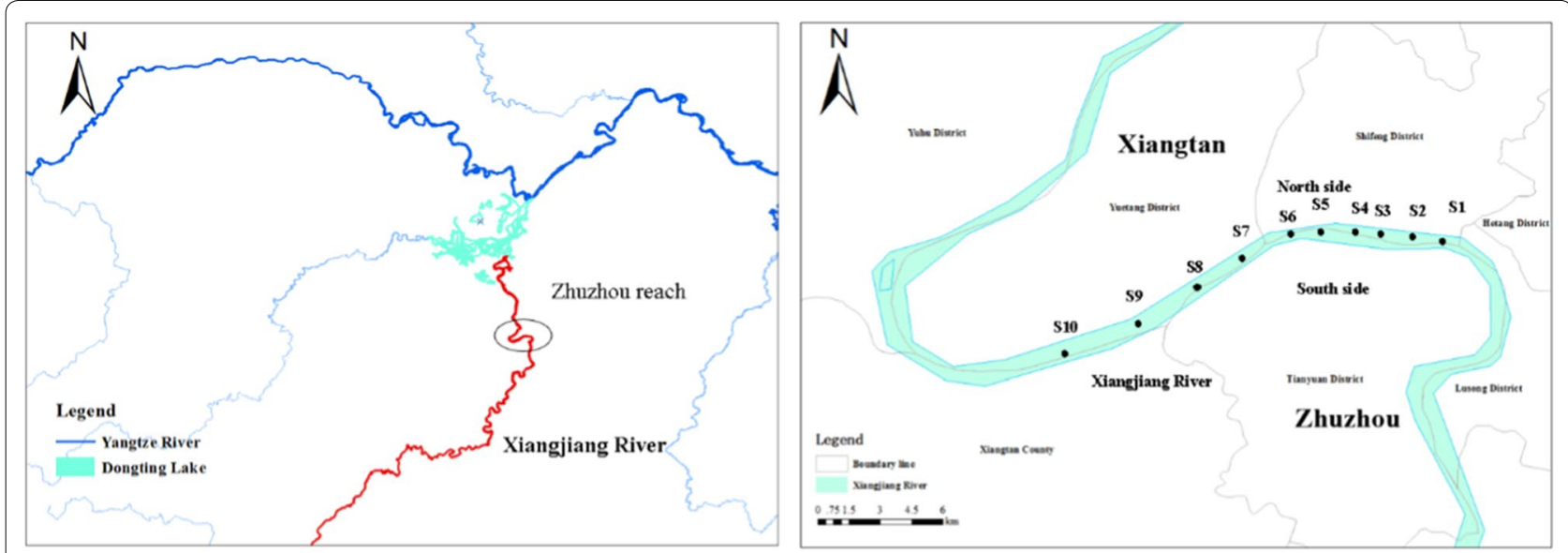

Fig. 1 Map of the Xiangjiang River Basin and the sampling sites 
top $5 \mathrm{~cm}$ layer of the riverbed. Each sample consists of a mixture of three samples from one sampling site. The collections from each transect were stored in acid-rinsed polyethylene plastic bags and transported immediately to the laboratory for storage at $-20{ }^{\circ} \mathrm{C}$ until further analysis, all sediment samples were analyzed within a week.

\section{Sample treatment and analysis}

Heavy metals in the sediment samples were determined at the Chinese Academy of Environmental Sciences according to published protocols [30,31]. Briefly, crude sediment samples were freeze-dried, finely ground, homogenized, and sieved (100 mesh, $150 \mu \mathrm{m})$. The prepared sample $(0.05 \mathrm{~g})$ was digested with mixed acid ( $5 \mathrm{~mL} \mathrm{HCl}, 3 \mathrm{~mL} \mathrm{HNO}$, $7 \mathrm{~mL} \mathrm{HF}, 0.25 \mathrm{~mL} \mathrm{HClO}_{4}$ ) in a Teflon beaker. After the digestion, the dissolved sample was diluted with $2 \% \mathrm{HNO}_{3}$, and the concentrations of heavy metals were analyzed using inductively coupled plasma mass spectrometry (ICP-MS, Agilent 7500 series, USA). The recoveries of standard reference metals were 90-110\%. For more details, refer to Lin et al. [32]. The content of organic matters $(\mathrm{OM})$ in the sediment was determined according to the standard methods for soil analysis [33]. Grain size was measured by a laser scattering particle size distribution analyzer (LA-300, Horiba, Kyoto, Japan) to determine the median sediment size $\left(D_{50}\right)$ and the fine particle $(<63 \mu \mathrm{m})$ content.

All reagents and solvents used in the sediment analysis were of analytical grade. The analytical procedure conformed to the certified standards of GBW07309 (China Stream Sediment Reference Materials). The results were within the acceptable level of uncertainty given by certified values.

\section{Pollution assessment of heavy metals Geoaccumulation}

The geoaccumulation index $\left(I_{\text {geo }}\right)$ formulated in 1969 is now one of the most widely used measures to evaluate heavy metal pollution in sediment because it can directly reflect the enrichment of exogenous heavy metals and provides consistent and comparable data [34, 35]. It is calculated as follows:

$$
I_{\text {geo }}=\log _{2}\left(\frac{C_{\text {sample }}}{1.5 C_{\text {backgroud }}}\right),
$$

where $C_{\text {sample }}$ is the concentration of the heavy metal in the sediment sample and $C_{\text {background }}$ is the geochemical background concentration ( $\mathrm{mg} \mathrm{kg}^{-1}$ ) of the heavy metal. A background matrix correction factor of 1.5 is adopted as a coefficient to compensate for weathering and lithogenic effects. Table 2 lists the background concentration of the investigated heavy metals in the Dongting
Lake sediments [36]. Pollution can be classified into seven classes based on the $I_{\text {geo }}$ value: Class $0\left(I_{\text {geo }} \leq 0\right)$, practically unpolluted; Class $1\left(0<I_{\text {geo }} \leq 1\right)$, unpolluted to moderately polluted; Class $2\left(1<I_{\text {geo }} \leq 2\right)$, moderately polluted; Class $3\left(2<I_{\text {geo }} \leq 3\right)$, moderately to heavily polluted; Class $4\left(3<I_{\text {geo }} \leq 4\right)$, heavily polluted; Class $5\left(4<I_{\text {geo }} \leq 5\right)$, heavily to extremely polluted, and Class 6 $\left(I_{\text {geo }}>5\right)$, extremely polluted [37].

\section{Assessment of potential ecological risk}

The potential ecological risk index (RI) formulated by Hakanson in 1980 was used here to quantify the level of ecological risk of heavy metals in sediment [38]. The RI assesses the combined ecological and environmental toxicity to provide an overall evaluation of the potential risks of heavy metal pollution, and is calculated as follows:

$$
\begin{aligned}
& E_{r}^{i}=T_{r}^{i} \frac{C_{\text {sample }}}{C_{\text {background }}}, \\
& \mathrm{RI}=\sum E_{r}^{i},
\end{aligned}
$$

where $E_{r}^{i}$ and $T_{r}^{i}$ are the potential ecological risk factor and the toxic response factor of the heavy metal, respectively, and $C_{\text {sample }}$ and $C_{\text {background }}$ are the measured and background concentration. The $T_{r}^{i}$ values for $\mathrm{Co}, \mathrm{Cd}, \mathrm{Ni}$, $\mathrm{Cr}, \mathrm{Cu}, \mathrm{As}, \mathrm{Pb}$, and $\mathrm{Zn}$, all taken from literature, are 5 , $30,5,2,5,10,5$, and 1 , respectively [39]. Table 1 lists the criteria for $E_{r}^{i}$ and RI.

\section{Statistical analysis}

PCA and RDA were performed using Canoco 5.0 (Biometris, Netherlands). Pearson's correlation analysis was conducted using SPSS 20.0 (SPSS Inc., Chicago, IL, USA). Data analyses and statistical tests were performed using Microsoft Excel 2010.

\section{Results and discussion}

\section{Occurrence and abundance of heavy metals in surface sediment}

Table 2 summarizes the minimum, maximum, and average concentrations (represented by dry weight) of the eight heavy metals in the surface sediment samples from the Zhuzhou Reach of the Xiangjiang River. All eight heavy metals were detected in all sediment samples. The concentration of $\mathrm{Cr}, \mathrm{Co}, \mathrm{Ni}, \mathrm{Cu}, \mathrm{Zn}, \mathrm{As}, \mathrm{Cd}$, and $\mathrm{Pb}$ ranged in 23.11-94.84, 5.26-25.24, 16.58-53.58, 20.54-159.3, 58.24-629.60, 34.74-186.80, 2.10-62.59, and $38.19-246.20 \mathrm{mg} \mathrm{kg}^{-1}$, respectively. The average concentration ranked in the order of $\mathrm{Zn}\left(257.17 \mathrm{mg} \mathrm{kg}^{-1}\right)>\mathrm{Pb}$ $\left(102.52 \mathrm{mg} \mathrm{kg}^{-1}\right)>\mathrm{As}\left(98.38 \mathrm{mg} \mathrm{kg}^{-1}\right)>\mathrm{Cu}\left(71.29 \mathrm{mg} \mathrm{kg}^{-1}\right)>$ $\mathrm{Cr}\left(59.71 \mathrm{mg} \mathrm{kg}^{-1}\right)>\mathrm{Ni}\left(36.29 \mathrm{mg} \mathrm{kg}^{-1}\right)>\mathrm{Cd}\left(23.31 \mathrm{mg} \mathrm{kg}^{-1}\right)>$ Co $\left(16.97 \mathrm{mg} \mathrm{kg}^{-1}\right)$. With the sediment of the Dongting 
Table 1 Levels of potential ecological risk for heavy metal in sediments

\begin{tabular}{llll}
\hline Range of $E_{r}^{i}$ value & Level of single metal ecological risk & Range of RI value & $\begin{array}{l}\text { Level of comprehensive } \\
\text { potential ecological risk }\end{array}$ \\
\hline$E_{r}^{i}<40$ & Low & $\mathrm{Rl}<150$ & Low \\
$40 \leq E_{r}^{i}<80$ & Moderate & $150 \leq \mathrm{Rl}<300$ & Moderate \\
$80 \leq E_{r}^{i}<160$ & Considerable & $300 \leq \mathrm{Rl}<600$ & Considerable \\
$160 \leq E_{r}^{i}<320$ & High & $600 \leq \mathrm{Rl}$ & High \\
$320 \leq E_{r}^{i}$ & Very high & & \\
\hline
\end{tabular}

Table 2 Concentration of heavy metals $\left(\mathrm{mg} \mathrm{kg}^{-1}\right)$ in the sediment of the Xiangjiang River and of other rivers in South China

\begin{tabular}{|c|c|c|c|c|c|c|c|c|c|}
\hline & $\mathrm{Cr}$ & Co & $\mathrm{Ni}$ & $\mathrm{Cu}$ & $\mathrm{Zn}$ & As & $\mathrm{Cd}$ & $\mathrm{Pb}$ & Refs. \\
\hline \multicolumn{10}{|l|}{ Xiangjiang River } \\
\hline $\begin{array}{l}\text { Zhuzhou Reach }(n=30) \\
\text { Minimum }\end{array}$ & 23.11 & 5.26 & 16.58 & 20.54 & 58.24 & 34.74 & 2.1 & 38.19 & This study \\
\hline $\begin{array}{l}\text { Zhuzhou Reach } \\
\text { Maximum }\end{array}$ & 94.84 & 25.24 & 53.58 & 159.3 & 629.60 & 186.80 & 62.59 & 246.20 & \\
\hline $\begin{array}{l}\text { Zhuzhou Reach } \\
\text { Average }\end{array}$ & 59.71 & 16.97 & 36.29 & 71.29 & 257.17 & 98.38 & 23.31 & 102.52 & \\
\hline Yongzhou Reach $(n=8)$ & 129.25 & 30.88 & 107.38 & 51.58 & 71.85 & 51.90 & 6.825 & 93.80 & [28] \\
\hline Hengyang Reach $(n=8)$ & 54.59 & - & - & 112.1 & 659.7 & 135.2 & 21.66 & 359.4 & [40] \\
\hline Changsha Reach $(n=12)$ & 95.10 & 19.45 & 48.70 & 73.13 & 465.7 & - & 13.63 & 140.10 & [28] \\
\hline Jinjiang River $(n=8)$ & 7.63 & 1.88 & 2.80 & 7.24 & 48.09 & 40.96 & 0.07 & 32.79 & [41] \\
\hline $\begin{array}{l}\text { Hanjiang River } \\
(n=6)\end{array}$ & 16.24 & 3.39 & 12.94 & 9.28 & 62.47 & 59.48 & 0.10 & 26.97 & [41] \\
\hline Yangtze River ( $n=34$ ) & 82.87 & - & 32.85 & 25.14 & 82.92 & 9.31 & 0.17 & 25.13 & [42] \\
\hline Dongting Lake (background) & 44 & 10.3 & 21.2 & 20 & 83.3 & 15 & 0.33 & 23.3 & [36] \\
\hline
\end{tabular}

Lake taken as the background and a reference point, the concentration of the heavy metals is 1.65-70.64 times higher in the sediment of the Zhuzhou Reach, thus indicating remarkable pollution. In particular, $\mathrm{Zn}$ and $\mathrm{Pb}$ have higher concentration than other heavy metals, which is consistent with the $\mathrm{Pb}-\mathrm{Zn}$ smelting activities around the Zhuzhou City. The lower concentration of other heavy metals is probably related to a less amount of discharge.

Table 2 also summarizes the concentration of the examined heavy metals in other reaches of the Xiangjiang River and in other rivers in South China [28, 36, 4042]. The distribution of heavy metals is clearly different among different reaches of the Xiangiiang River (including Yongzhou, Hengyang, Zhuzhou, and Changsha). The Yongzhou Reach is the upstream and has the lowest concentration of heavy metals (except for $\mathrm{Cr}$ ) in sediment [28]. The Hengyang Reach is located between Yongzhou and Zhuzhou and has the highest concentration of $\mathrm{Cu}$, $\mathrm{Zn}, \mathrm{As}$, and $\mathrm{Pb}$ in sediment [40]. For the Zhuzhou Reach, the concentration of $\mathrm{Co}, \mathrm{Ni}$ in the sediment is generally lower, but the concentration of $\mathrm{Cd}$ is the highest. The
Changsha Reach is the downstream and does not have a heavy metal with particularly high or low concentration [28]. The distinct distribution of different heavy metals may be associated with specific local mining activities. However, the sediment of the Xiangiiang River is clearly more polluted by heavy metals than the sediment of other rivers in South China, including the Jinjiang River, Hanjiang River, and Yangtze River [41, 42]. The concentration of $\mathrm{Zn}$ seems to be the highest among the examined heavy metals for all rivers, possibly due to regional $\mathrm{Zn}$ production. This high level of $\mathrm{Zn}$ is not specific to Hunan. In fact, for the past 20 years in China, Zn has an annual production higher than all seven other heavy metals except $\mathrm{Cu}$ [43].

\section{Spatial distribution of heavy metals}

Figure 2 illustrates the concentration of the heavy metals at S1-S10. The total concentration of heavy metals gradually increases as the water flows through the Zhuzhou Reach and peaks at S6 (1042.00 $\left.\mathrm{mg} \mathrm{kg}^{-1}\right)$, then suddenly decreases sharply at S7 to only $280.33 \mathrm{mg} \mathrm{kg}^{-1}$, but rises again to about $650 \mathrm{mg} \mathrm{kg}^{-1}$ at the downstream 


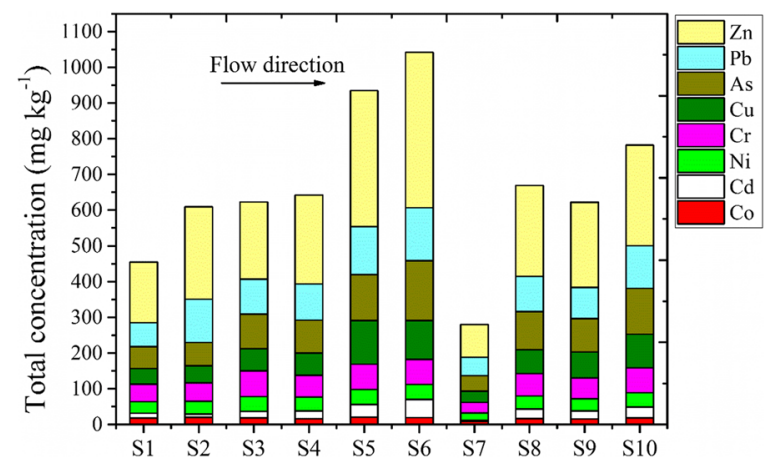

Fig. 2 Spatial distribution of heavy metals in the sediment of the Zhuzhou Reach

sites $\mathrm{S} 8-\mathrm{S} 10 . \mathrm{Zn}$ has the highest concentration at S6 (435.84 mg kg-1) and then the next highest at S5 $\left(127.04 \mathrm{mg} \mathrm{kg}^{-1}\right)$. There is no significant difference in the concentrations of heavy metals within the upstream (S1S4) and within the downstream (S8-S10), but there is a significant difference within the midstream (S5-S7).

The concentration of heavy metals is the highest at S6, possibly due to the discharge of local pollution sources. Other factors such as the grain size and the OM content of sediment can also affect the concentration of heavy metals. For instance, sediment with a higher content of OM adsorbs more heavy metals [44]. Indeed, Additional file 1: Table S1 shows that the OM content of S6 is the highest among all sites. In fact, S6 is located in the middle of the surveyed area and there is a sandbar between S6 and S7. This geographic feature may increase the deposition of particles carrying heavy metals into the sediment of S6.

Most heavy metals have slightly higher concentration in the middle of the river than on the south side, and all heavy metals have significantly higher concentrations on the north side (Fig. 3). In particular, the concentration of $\mathrm{Zn}$ and $\mathrm{Pb}$ in the north is nearly twice as much as in the middle and the south. The asymmetrical concentration can be associated with the nonferrous metal mining and smelting plants in the north that produce $\mathrm{Zn}, \mathrm{Pb}$, and alloys and discharge substantial amount of wastewater.

\section{Assessment of heavy metal pollution}

Many measures have been used in literature to assess heavy metal pollution in sediment, e.g., the geoaccumulation index, the potential ecological risk index, the enrichment factor, etc. [45-47]. In this study, we used $I_{\text {geo }}$ and RI to assess heavy metal pollution in the sediment of the Zhuzhou Reach with reference to the concentration of Dongting Lake sediments as the background.

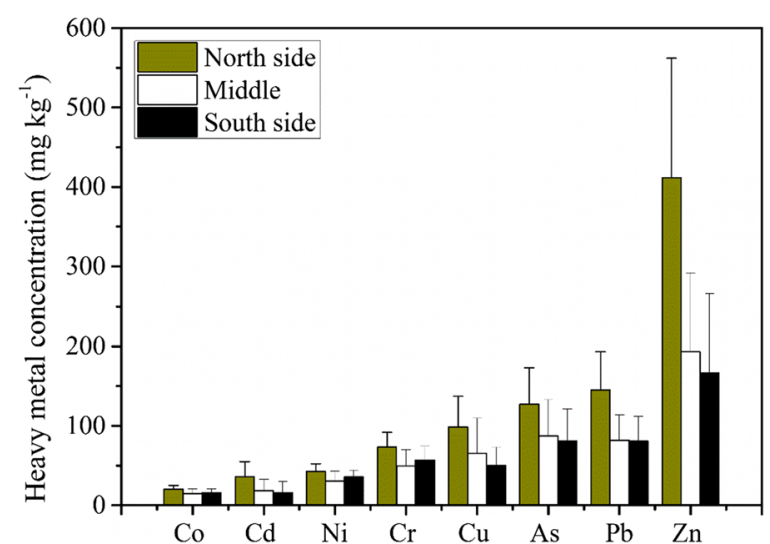

Fig. 3 Heavy metal concentration in the sediment collected at the south side, the north side, and in the middle of the river

\section{Assessment of $I_{\text {geo }}$}

Figure 4a shows a boxplot of the average $I_{\text {geo }}$ values for the eighty heavy metals, which can be ranked in descending order as follows: $\mathrm{Cd}(5.01)>\mathrm{As}(1.94)>\mathrm{Pb}(1.40)>\mathrm{Zn}$ $(0.74)>\mathrm{Ni}(0.11)>\mathrm{Co}(0.04)>\mathrm{Cu}(0.43)>\mathrm{Cr}(-0.26)$. The pollution levels of the metals are thus segmented into 4 classes according to the $I_{\text {geo }}$ values. That is, the Zhuzhou Reach is extremely polluted by $\mathrm{Cd}$ (Class 6 ), moderately to heavily polluted by $\mathrm{As}$ and $\mathrm{Pb}$ (Class 2), unpolluted to moderately polluted by $\mathrm{Zn}, \mathrm{Ni}, \mathrm{Co}$, and $\mathrm{Cu}$ (Class 1 ), and practically unpolluted by $\mathrm{Cr}$ (Class 0 ).

The different colors in Fig. 4b denote the class of $I_{\text {geo }}$ for each heavy metal at $\mathrm{S} 1-\mathrm{S} 10$. The pollution of Cd is highly variable geographically, from Class 3 (S7) up to Class 6 (S3-S6, S8, S10). The pollution of As and $\mathrm{Pb}$ varies from Class 1 to Class 3, and the pollution of all other metals stay within two neighboring classes. The pollution of $\mathrm{Cr}$, $\mathrm{Co}$, and $\mathrm{Ni}$ appears to be mild (Class $0 \mathrm{Cr}$ for $60 \%$, Class 1 Co for $70 \%$, Class $1 \mathrm{Ni}$ for $80 \%$ of the 10 sites). Pollution is more severe midstream (S5-S7) and downstream (S8S10) than upstream (S1-S4).

\section{Assessment of potential ecological risk}

Additional file 1: Table S2 lists the calculated $E_{r}^{i}$ values of the heavy metals, from which the RI values were derived (Fig. 5). The RI value of the whole surveyed area ranged from 422.31 to 4854.41 , with an average of 2246.64 , thus indicating high ecological risk (Table 1) from heavy metal pollution. The sediment of S7 has RI $>300$, and all others even have RI $>600$ (Fig. 5). Among the tested metals, $\mathrm{Cd}$ creates very high ecological risk to the sediment at all sites $\left(E_{r}^{i}>320\right)$. The level of single metal ecological risk of As is the lowest at $\mathrm{S} 7\left(E_{r}^{i}=28.84\right)$, considerable at S5, $\mathrm{S} 6$, and S10, and moderate at all other sites. Other heavy 


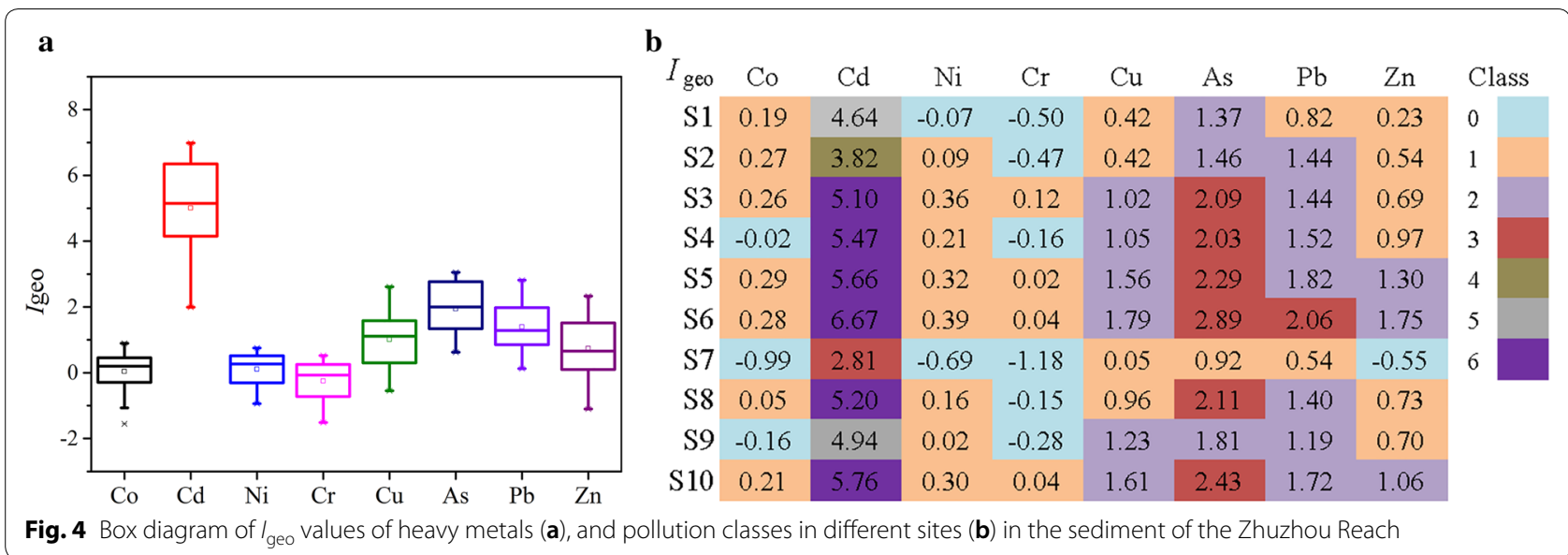

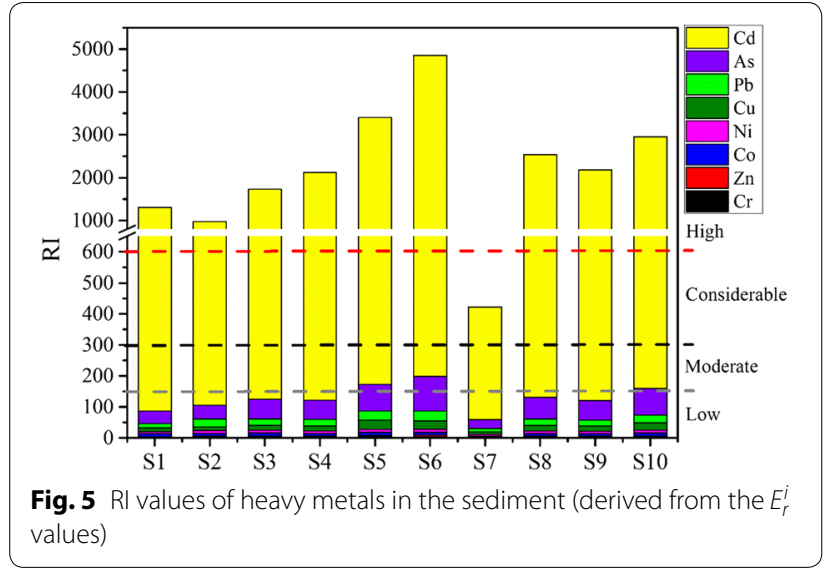

metals $(\mathrm{Pb}, \mathrm{Cu}, \mathrm{Ni}, \mathrm{Co}, \mathrm{Zn}$, and $\mathrm{Cr})$ have low ecological risk in all sediments $\left(E_{r}^{i}<40\right)$.

\section{Identification of the sources of heavy metals}

Analyzing the sources of heavy metals can help understand their distribution. Principal components analysis (PCA) and Pearson's correlation analysis were used to analyze the relationship and source of the heavy metals $[28,48]$.

In this study, PCA was performed based on the determined concentrations of heavy metals with varimax rotation. The Kaiser-Meyer-Olkin (KMO) test gives $0.76(>0.7)$ and Bartlett test gives $397.58(\mathrm{df}=28$, $p<0.001$ ), both indicating strong correlation among variables and confirming that PCA can be used to reduce the dimensionality of variables. In the PCA results (Fig. 6 and Additional file 1: Figure S1), PC1 accounts for $51.30 \%$ of the variation, and its representative congeners include $\mathrm{Cd}, \mathrm{Zn}, \mathrm{As}, \mathrm{Cu}$, and $\mathrm{Pb}$, implying a common source that is possibly exogenous discharge [24, 49]. This speculation is further supported by the Pearson's

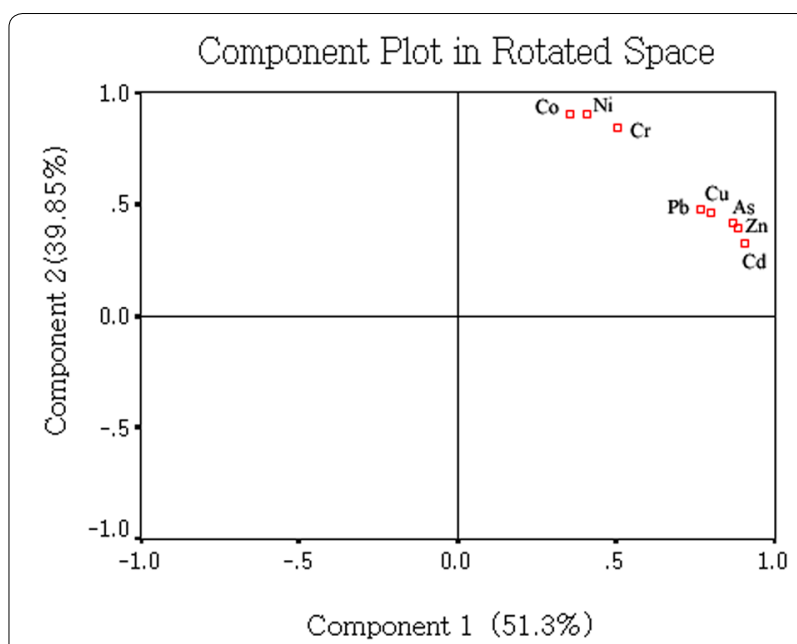

Fig. 6 Principal component profile of heavy metals in the sediment of different sampling sites

correlation analysis (Fig. 7), in which all heavy metals are significantly positively correlated with each other $(r>0.60, p<0.01)$. Note that $\mathrm{Pb}$ and $\mathrm{Zn}$, the main pollutants of the current $\mathrm{Pb}-\mathrm{Zn}$ mining and smelting industry in China [50,51], have a particularly high correlation $(r=0.95, p<0.01)$. The PC2 accounts for $39.85 \%$ of the variation, and its representative congeners include $\mathrm{Co}$, $\mathrm{Ni}$, and $\mathrm{Cr}$. The PCA results also indicate that at sites 5 , the sediment at north side is affected by $\mathrm{Cd}, \mathrm{Zn}, \mathrm{As}, \mathrm{Cu}$, $\mathrm{Pb}$ (Additional file 1: Figure S1), while the sediment at the middle of river is mainly affected by $\mathrm{Co}, \mathrm{Ni}$, and $\mathrm{Cr}$. It may be due to the effects of hydrodynamics or other sources, in the pollution assessment, $\mathrm{Cr}, \mathrm{Ni}$, and $\mathrm{Co}$ all have lower $I_{\text {geo }}$ and lower $E_{r}^{i}$. Therefore, they may have been derived from natural processes such as soil erosion and rock weathering. This hypothesis is also supported by previous study $[28,46]$. 


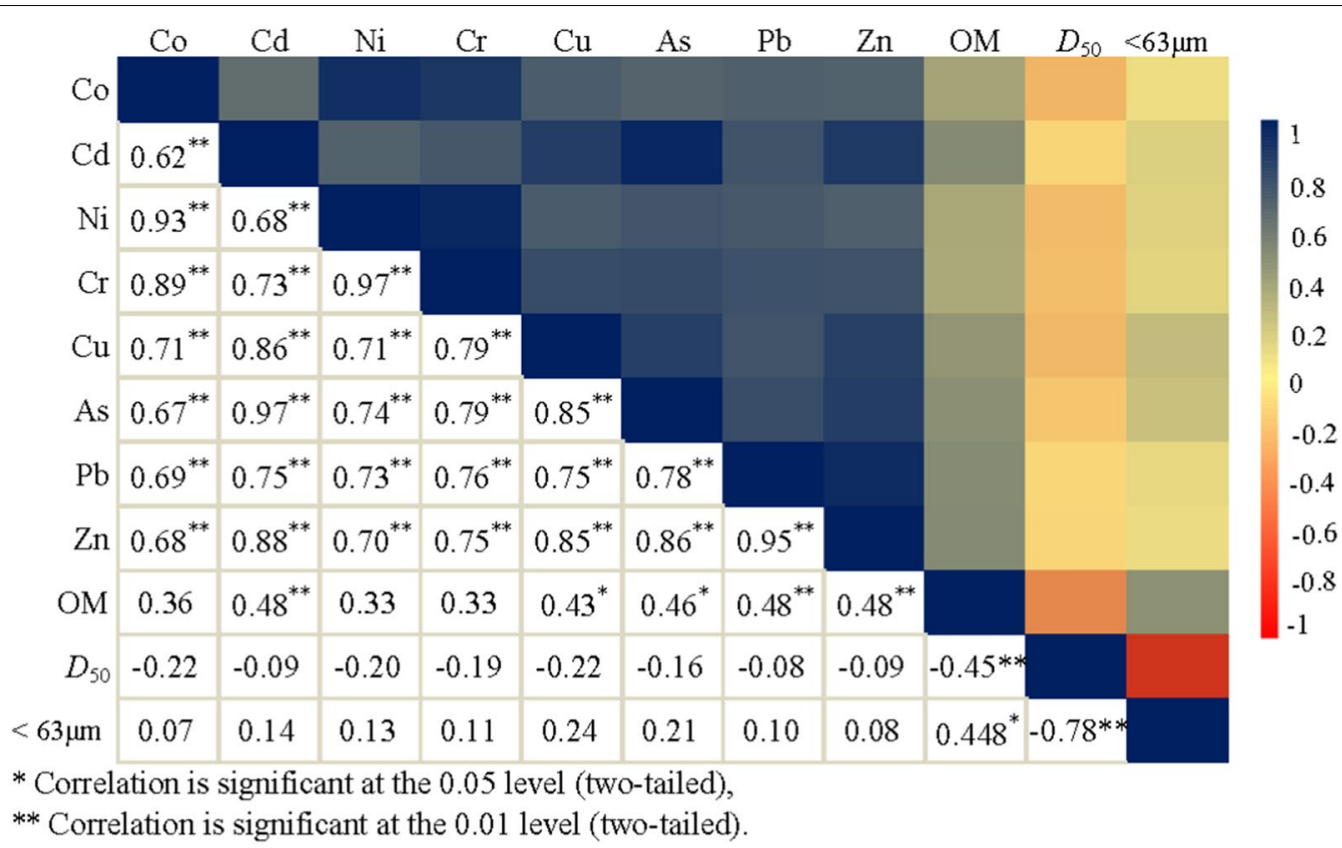

Fig. 7 Pearson's correlation coefficients ( $r$ ) of heavy metals and environmental factors in the sediment of the Zhuzhou Reach

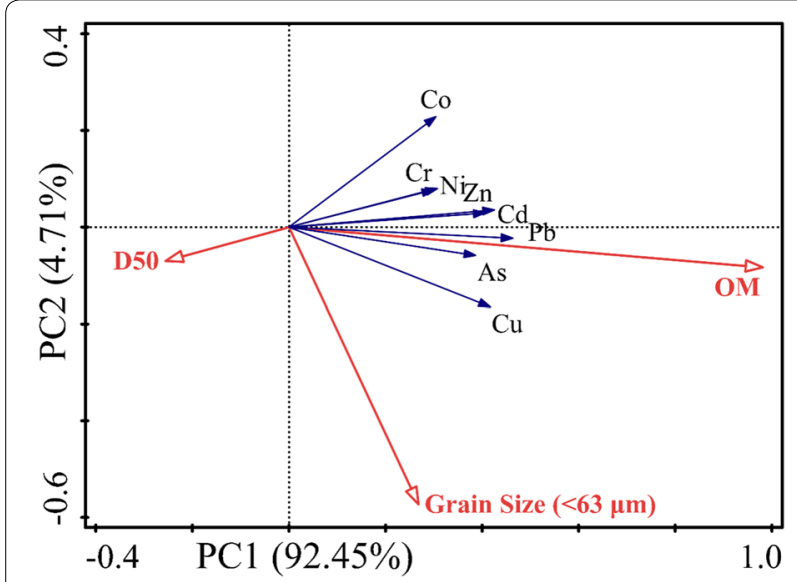

Fig. 8 Redundancy analysis diagram between heavy metals and sediment variables

\section{Effects of environmental variables on the heavy metals}

Many environmental factors affect the distribution of heavy metals in sediment. The redundancy analysis (RDA) was used here to further investigate the environmental variables that affect the distribution of heavy metal. The considered environmental variables include the organic matter content $(\mathrm{OM})$, median size $\left(D_{50}\right)$, and fine particle content (grain size $<63 \mu \mathrm{m}$ ) of the sediment samples (Additional file 1: Table S1). In the RDA result (Fig. 8), the angle between the environmental variable and the heavy metal reflects their relevance. The concentrations of heavy metal are positively correlated to OM, i.e., sediment with relatively high OM tends to be more polluted by heavy metals. It was previously suggested that $\mathrm{OM}$ in sediment can adsorb heavy metals from the environment [52]. The grain size distribution of sediment is also an important factor that affects the enrichment of heavy metals [53]. Sediment particles can adsorb heavy metals by both physical and chemical processes. Physical adsorption is mainly related to the specific surface area of the sediment, and a smaller particle size of the sediment gives larger surface area and thus stronger adsorption capacity. Chemical adsorption is related to the active components contained in sediment particles, and the sediment tends to adsorb a greater amount of active components when it has smaller particle size [44, $54,55]$. Therefore, heavy metals are generally negatively correlated with $D_{50}$. The fine particle content (grain size $<63 \mu \mathrm{m})$ has influences on the heavy metal concentration. Figure 7 also shows the correlation between the environmental variables and the heavy metals.

\section{Conclusions}

Heavy metal pollutants in river sediment have been a serious environmental concern in aquatic ecosystems. This study examines eight heavy metals in the surface sediment of the Zhuzhou Reach of the Xiangjiang River. All eight heavy metals were detected at all sampling sites, with a concentration higher than the background value. 
Their average concentration fell in the order of $\mathrm{Zn}>\mathrm{Pb}$ $>\mathrm{As}>\mathrm{Cu}>\mathrm{Cr}>\mathrm{Ni}>\mathrm{Cd}>\mathrm{Co}$. Pollution appeared more serious in the midstream and on the northern side of the Xiangjiang River, possibly due to point source pollution nearby. Among the selected heavy metals, Cd presents very high ecological risk and should be carefully monitored and remediated. Most other heavy metals incur limited, if any, pollution according to the risk assessment. It was found from PCA and correlation analysis that $\mathrm{Pb}$, $\mathrm{Zn}, \mathrm{As}, \mathrm{Cu}$, and $\mathrm{Cd}$ are mainly originated from anthropogenic activities (industrial wastewater and mineral exploitation), whereas $\mathrm{Cr}, \mathrm{Co}$, and $\mathrm{Ni}$ can be attributed to the release from natural sources. Organic matter and grain size are the main factors affecting the distribution of heavy metals in the sediment, and heavy metals become enriched in the sediment when its organic matter is higher and particle size is smaller.

\section{Supplementary information}

Supplementary information accompanies this paper at https://doi. org/10.1186/s12302-020-00305-w.

Additional file 1: Table S1. Parameters of sediment samples. All values are given as mean values with standard deviation. Table $\mathbf{S 2}$. $E_{r}^{i}$ values of heavy metals in sediment. All values are given as mean values with standard Figure S1. PCA score plot of heavy metals in the sediment of different sampling sites.

\section{Abbreviations}

PCA: Principal component analysis; RDA: Redundancy analysis; I geo: Geoaccumulation index; RI: Potential ecological risk index; OM: Organic matters; $D_{50}$ : Median size.

\section{Acknowledgements}

Not applicable.

\section{Authors' contributions}

$\mathrm{ZH}$ and $\mathrm{XZ}$ were involved in the experiments and manuscript writing. $\mathrm{ZH}$ was responsible for the data analysis. $C L$ and JD collected samples. ZH and BZ designed the study. XZ and BZ contributed to correction of the manuscript. All authors read and approved the final manuscript.

\section{Funding}

This work was supported by the Water Pollution Control and Management (No. 2018ZX07502-001-005).

\section{Availability of data and materials}

The datasets obtained and analyzed in the current study are available from the corresponding author on reasonable request.

\section{Ethics approval and consent to participate}

Not applicable.

\section{Consent for publication}

Not applicable.

\section{Competing interests}

The authors declare that they have no competing interests.

\section{Author details}

${ }^{1}$ National Engineering Laboratory for Lake Pollution Control and Ecological Restoration, State Environmental Protection Key Laboratory of Drinking Water
Source Protection, Chinese Research Academy of Environmental Sciences, Beijing 100012, China. ${ }^{2}$ Key Laboratory of Yangtze River Water Environment, Ministry of Education, College of Environmental Science and Engineering, Tongji University, Shanghai 200092, China.

Received: 18 December 2019 Accepted: 9 February 2020

Published online: 26 February 2020

\section{References}

1. Zhang C, Yu Z-G, Zeng G-M, Jiang M, Yang Z-Z, Cui F, Zhu M-Y, Shen L-Q, Hu L (2014) Effects of sediment geochemical properties on heavy metal bioavailability. Environ Int 73:270-281

2. Bryan GW, Langston WJ (1992) Bioavailability, accumulation and effects of heavy metals in sediments with special reference to United Kingdom estuaries: a review. Environ Pollut 76:89-131

3. Redwan M, Elhaddad E (2017) Heavy metals seasonal variability and distribution in Lake Qaroun sediments, El-Fayoum, Egypt. J Afr Earth Sci 134:48-55

4. Jordanova M, Hristovski S, Musai M, Boskovska V, Rebok K, DinevskaKovkarovska S, Melovski L (2018) Accumulation of heavy metals in some organs in barbel and chub from Crn Drim River in the Republic of Macedonia. Bull Environ Contam Toxicol 101:392-397

5. Chen R, Chen H, Song L, Yao Z, Meng F, Teng Y (2019) Characterization and source apportionment of heavy metals in the sediments of Lake Tai (China) and its surrounding soils. Sci Total Environ 694:133819

6. Li Z, Liu J, Chen H, Li Q, Yu C, Huang X, Guo H (2019) Water environment in the Tibetan Plateau: heavy metal distribution analysis of surface sediments in the Yarlung Tsangpo River Basin. Environ Geochem Health $17: 1-9$

7. Nguyen CC, Hugie CN, Kile ML, Navab-Daneshmand T (2019) Association between heavy metals and antibiotic-resistant human pathogens in environmental reservoirs: a review. Front Environ Sci Eng 13:46

8. Jia L, Liu H, Kong Q, Li M, Wu S, Wu H (2019) Interactions of high-rate nitrate reduction and heavy metal mitigation in iron-carbon-based constructed wetlands for purifying contaminated groundwater. Water Res 169:115285

9. Akcay H, Oguz A, Karapire C (2003) Study of heavy metal pollution and speciation in Buyak Menderes and Gediz river sediments. Water Res 37(4):813-822

10. Olivares-Rieumont S, de la Rosa D, Lima L, Graham DW, D'Alessandro K, Borroto J, Martinez F, Sanchez J (2005) Assessment of heavy metal levels in Almendares River sediments—-Havana City, Cuba. Water Res 39:3945-3953

11. Wang Y, Yang Z, Shen Z, Tang Z, Niu J, Gao F (2011) Assessment of heavy metals in sediments from a typical catchment of the Yangtze River, China. Environ Monit Assess 172:407-417

12. Li X, Wang Y, Li B, Feng C, Chen Y, Shen Z (2013) Distribution and speciation of heavy metals in surface sediments from the Yangtze estuary and coastal areas. Environ Earth Sci 69:1537-1547

13. Pejman A, Bidhendi GN, Ardestani M, Saeedi M, Baghvand A (2015) A new index for assessing heavy metals contamination in sediments: a case study. Ecol Ind 58:365-373

14. Huang Z, Zhao W, Xu T, Zheng B, Yin D (2019) Occurrence and distribution of antibiotic resistance genes in the water and sediments of Qingcaosha Reservoir, Shanghai. China. Environ Sci Eur 31:1-9

15. Shyleshchandran MN, Mohan M, Ramasamy EV (2018) Risk assessment of heavy metals in Vembanad Lake sediments (south-west coast of India), based on acid-volatile sulfide (AVS)-simultaneously extracted metal (SEM) approach. Environ Sci Pollut Res 25:7333-7345

16. Liu M, Zhong J, Zheng X, Yu J, Liu D, Fan C (2018) Fraction distribution and leaching behavior of heavy metals in dredged sediment disposal sites around Meiliang Bay, Lake Taihu (China). Environ Sci Pollut Res 25:9737-9744

17. Kouidri M, Youcef ND, Benabdellah I, Ghoubali R, Bernoussi A, Lagha A (2016) Enrichment and geoaccumulation of heavy metals and risk assessment of sediments from coast of Ain Temouchent (Algeria). Arab J Geosci 9:354

18. Liang A, Wang Y, Guo H, Bo L, Zhang S, Bai Y (2015) Assessment of pollution and identification of sources of heavy metals in the sediments of 
Changshou Lake in a branch of the Three Gorges Reservoir. Environ Sci Pollut Res 22:16067-16076

19. Krasnici N, Dragun Z, Erk M, Raspor B (2013) Distribution of selected essential ( $\mathrm{Co}, \mathrm{Cu}, \mathrm{Fe}, \mathrm{Mn}, \mathrm{Mo}, \mathrm{Se}$, and $\mathrm{Zn}$ ) and nonessential $(\mathrm{Cd}, \mathrm{Pb})$ trace elements among protein fractions from hepatic cytosol of European chub (Squalius cephalus L.). Environ Sci Pollut Res 20:2340-2351

20. Fu J, Zhao C, Luo Y, Liu C, Kyzas GZ, Luo Y, Zhao D, An S, Zhu H (2014) Heavy metals in surface sediments of the Jialu River, China: their relations to environmental factors. J Hazard Mater 270:102-109

21. Chai L, Wang Z, Wang Y, Yang Z, Wang H, Wu X (2010) Ingestion risks of metals in groundwater based on TIN model and dose-response assessment-a case study in the Xiangjiang watershed, central-south China. Sci Total Environ 408:3118-3124

22. Hu H, Jin Q, Kavan P (2014) A study of heavy metal pollution in china: current status, pollution-control policies and countermeasures. Sustainability 6:5820-5838

23. Chen J-Q, Wang Z-X, Wu X, Zhu J-J, Zhou W-B (2011) Source and hazard identification of heavy metals in soils of Changsha based on TIN model and direct exposure method. Trans Nonferr Metals Soc China 21:642-651

24. Mao L, Mo D, Guo Y, Fu Q, Yang J, Jia Y (2013) Multivariate analysis of heavy metals in surface sediments from lower reaches of the Xiangjiang River, southern China. Environ Earth Sci 69:765-771

25. Fang X, Peng B, Wang X, Song Z, Zhou D, Wang Q, Qin Z, Tan C (2019) Distribution, contamination and source identification of heavy metals in bed sediments from the lower reaches of the Xiangjiang River in Hunan province, China. Sci Total Environ 689:557-570

26. Li H, Yang J, Ye B, Jiang D (2019) Pollution characteristics and ecological risk assessment of 11 unheeded metals in sediments of the Chinese Xiangjiang River. Environ Geochem Health 41:1459-1472

27. Jiang M, Zeng G, Zhang C, Ma X, Chen M, Zhang J, Lu L, Yu Q, Hu L, Liu L (2013) Assessment of heavy metal contamination in the surrounding soils and surface sediments in Xiawangang River, Qingshuitang District. PloS ONE 8:e71176

28. Chai L, Li H, Yang Z, Min X, Liao Q, Liu Y, Men S, Yan Y, Xu J (2017) Heavy metals and metalloids in the surface sediments of the Xiangiiang River, Hunan, China: distribution, contamination, and ecological risk assessment. Environ Sci Pollut Res 24:874-885

29. Peng B, Tang X, Yu C, Tan C, Yin C, Yang G, Liu Q, Yang K, Tu X (2011) Geochemistry of trace metals and $\mathrm{Pb}$ isotopes of sediments from the lowermost Xiangjiang River, Hunan Province (P. R. China): implications on sources of trace metals. Environ Earth Sci 64:1455-1473

30. Wang H, Wang J, Liu R, Yu W, Shen Z (2015) Spatial variation, environmental risk and biological hazard assessment of heavy metals in surface sediments of the Yangtze River estuary. Mar Pollut Bull 93:250-258

31. Liao Y, Min X, Yang Z, Chai L, Zhang S, Wang Y (2014) Physicochemical and biological quality of soil in hexavalent chromium-contaminated soils as affected by chemical and microbial remediation. Environ Sci Pollut Res 21:379-388

32. Lin C, He M, Liu X, Guo W, Liu S (2013) Contamination and ecological risk assessment of toxic trace elements in the Xi River, an urban river of Shenyang city, China. Environ Monit Assess 185:4321-4332

33. Huang Y, Fu C, Li Z, Fang F, Ouyang W, Guo J (2019) Effect of dissolved organic matters on adsorption and desorption behavior of heavy metals in a water-level-fluctuation zone of the Three Gorges Reservoir, China. Ecotoxicol Environ Saf 185:109695

34. Audry S, Schafer J, Blanc G, Jouanneau JM (2004) Fifty-year sedimentary record of heavy metal pollution ( $\mathrm{Cd}, \mathrm{Zn}, \mathrm{Cu}, \mathrm{Pb})$ in the Lot River reservoirs (France). Environ Pollut 132:413-426

35. Tran Thi Thu D, Cappuyns V, Swennen R, Nguyen Ky P (2013) From geochemical background determination to pollution assessment of heavy metals in sediments and soils. Rev Environ Sci Bio-Technol 12:335-353

36. Qian Y, Zheng MH, Gao L, Zhang B, Liu W, Jiao W, Zhao X, Xiao K (2005) Heavy metal contamination and its environmental risk assessment in surface sediments from Lake Dongting, People's Republic of China. Bull Environ Contam Toxicol 75(1):204-210
37. Chowdhury R, Favas PJC, Pratas J, Jonathan MP, Ganesh PS, Sarkar SK (2015) Accumulation of trace metals by mangrove plants in Indian Sundarban Wetland: prospects for phytoremediation. Int J Phytorem 17:885-894

38. Hakanson L (1980) An ecological risk index for aquatic pollution-control-a sedimentological approach. Water Res 14:975-1001

39. Teng Y, Wu J, Lu S, Wang Y, Jiao X, Song L (2014) Soil and soil environmental quality monitoring in China: a review. Environ Int 69:177-199

40. Tang J, Chai L, Li H, Yang Z, Yang W (2018) A 10-year statistical analysis of heavy metals in river and sediment in Hengyang segment, Xiangjiang River Basin, China. Sustainability 10:1057

41. Zhuang Q, Li G, Liu Z (2018) Distribution, source and pollution level of heavy metals in river sediments from South China. CATENA 170:386-396

42. He Z, Li F, Dominech S, Wen X, Yang S (2019) Heavy metals of surface sediments in the Changjiang (Yangtze River) Estuary: distribution, speciation and environmental risks. J Geochem Explor 198:18-28

43. Fu Z, Wu F, Chen L, Xu B, Feng C, Bai Y, Liao H, Sun S, Giesy JP, Guo W (2016) Copper and zinc, but not other priority toxic metals, pose risks to native aquatic species in a large urban lake in Eastern China. Environ Pollut 219:1069-1076

44. Liang J, Liu J, Xu G, Chen B (2019) Distribution and transport of heavy metals in surface sediments of the Zhejiang nearshore area, East China Sea: sedimentary environmental effects. Mar Pollut Bull 146:542-551

45. Jiang Y, Chao S, Liu J, Yang Y, Chen Y, Zhang A, Cao H (2017) Source apportionment and health risk assessment of heavy metals in soil for a township in Jiangsu Province, China. Chemosphere 168:1658-1668

46. Chen Y, Jiang $X$, Wang $Y$, Zhuang D (2018) Spatial characteristics of heavy metal pollution and the potential ecological risk of a typical mining area: a case study in China. Process Saf Environ Prot 113:204-219

47. Grygar TM, Popelka J (2016) Revisiting geochemical methods of distinguishing natural concentrations and pollution by risk elements in fluvial sediments. J Geochem Explor 170:39-57

48. Jiang D, Wang Y, Zhou S, Long Z, Liao Q, Yang J, Fan J (2019) Multivariate analyses and human health assessments of heavy metals for surface water quality in the Xiangjiang River Basin, China. Environ Toxicol Chem 38:1645-1657

49. Zhu J, Zhang J, Li Q, Han T, Xie J, Hu Y, Chai L (2013) Phylogenetic analysis of bacterial community composition in sediment contaminated with multiple heavy metals from the Xiangjiang River in China. Mar Pollut Bull 70:134-139

50. Qi J, Zhang H, Li X, Lu J, Zhang G (2016) Concentrations, spatial distribution, and risk assessment of soil heavy metals in a $\mathrm{Zn}-\mathrm{Pb}$ mine district in southern China. Environ Monit Assess 188:413

51. Dong $Y$, Zhong N, Yang $X$ (2002) Current progress in evaluation indexes for heavy metals pollution in soils. Trace Elem Sci 9:11-17

52. Damak M, Fourati R, Ellech B, Kallel M (2019) Assessment of organic and metallic contamination in the surface sediment of Monastir Bay (Eastern Tunisia): spatial distribution, potential sources, and ecological risk assessment. Mar Pollut Bull 149:110500

53. Zonta R, Cassin D, Pini R, Dominik J (2019) Assessment of heavy metal and As contamination in the surface sediments of Po delta lagoons (Italy). Estuar Coast Shelf Sci 225:106235

54. Ugochukwu N, Mohamed I, Ali M, labal J, Fu Q, Zhu J, Jiang G, Hu H (2013) Impacts of inorganic ions and temperature on lead adsorption onto variable charge soils. CATENA 109:103-109

55. Hegedusova A, Hegedus O, Toth T, Vollmannova A, Andrejiova A, Slosar M, Mezeyova I, Pernyeszi T (2016) Adsorption processes of lead ions on the mixture surface of bentonite and bottom sediments. Bull Environ Contam Toxicol 97:876-880

\section{Publisher's Note}

Springer Nature remains neutral with regard to jurisdictional claims in published maps and institutional affiliations. 